\title{
An inevitable consequence
}

Viebig RG. An inevitable consequence. Arq Gastroenterol. 2019;56(4):331-2.

Swallowing: initial process of digestion understood by a simple word. This act performed countless times a day is extremely complex and indispensable to our survival. Voluntary process, sometimes did as reflex, has its learning initiated at three months of gestation. The neural integration of several muscular complexes, supported by cartilaginous and bony structures, determines the proper physicochemical preparation to trigger a refined sequence of events that culminate with the ingestion of the bolus. This mechanism combines the pleasure of feeding, flavor and satiety, primordial facts to maintain the quality of life.

Over the past 20 years, the Archives of Gastroenterology have followed and encouraged the publications where the key words predominate: dysphagia, swallowing, videofluoroscopy of swallowing and other related. The magazine regularly receives original contributions and review articles in the area. Traditionally, the journal supports and encourages physicians and speech therapists who venture into the field of Dysphagia and who today form a considerable contingent of professionals not only investigating the swallowing phenomena but putting into practice the knowledge acquired for the benefit of patients. In these last 25 years, I personally follow the evolution of these experts and through this exchange of experiences I am sure that Brazil is one of the countries with the highest degree of specialization in the treatment of patients with dysphagia, both in the hospital, outpatient and in the field of research.

As a natural consequence of the intensity of information exchange and the integration of people interested in dysphagia, an important step has been taken in our history: the foundation of a professional association that will seal the interests of this collectivity: the Brazilian Academy of Dysphagia (ABD).
This meeting of physicians, speech therapists, nurses, physiotherapists, nutrologists in an association, reproduces what happens in our professional daily life. The multidisciplinary activity in acting on dysphagia is the domain of all these professionals who work in consonance to refer patients to the best solution or control of their disorders.

Swallowing was legated to a second plan for many years by the scientific community but is currently no longer observed as a simple phenomenon and its field of interest for clinical research is enormous. Some researchers have stood out in the last two decades because they are pioneers and insistent to publish their results into the Archives of Gastroenterology. Their names are listed in the references section ${ }^{(1-24)}$.

As associate editors, for many years our periodic have been relying on assistance from Dr. Ana Maria Furkim, Dr. Roberta Gonçalves, Dr. Milton Costa, Dr. Roberto Dantas and Dr. Evaldo Ducheaux de Melo, whose contribution is invaluable to science, to his disciples and consequently to dysphagic patients.

Crowding this interaction of many years, the Archives of Gastroenterology will be included as official organ of the Brazilian Academy of Dysphagia from 2020 ahead. The position of associate Editor for one of its members is opened, strengthening this partnership, making the periodical a way of disseminating and promoting the academic and scientific activity of those involved with dysphagia.

Wellcome ABD!

Viebig RG. Uma consequência inevitável. Arq Gastroenterol. 2019;56(4):331-2.

* Hospital IGESP, Motilidade Digestiva e Neurogastroenterologia (MoDiNe), São Paulo, SP, Brasil. ORCID: 0000-0002-6541-0401 


\section{REFERENCES}

1. Dantas RO, Miranda AL. Sequential swallows have no influence on esophageal contractions of patients with iron deficiency anemia. Arq Gastroenterol. 2004;41:27-32.

2. Yamada EK, Siqueira KO, Xerez D, Koch HA, Costa MMB. [The influence of oral and pharyngeal phases on the swallowing dynamic]. [Article in Portuguese] Arq Gastroenterol. 2004;41:18-23. ISSN 0004-2803

3. Suzuki HS, Nasi A, Ajzen S, Bilton T, Sanches EP. [Clinical and radiological study of swallowing in patients with deglutition disorders, classified into two age groups: adults and older people]. [Article in Portuguese]. Arq Gastroenterol. 2006;43:201-5.

4. Alvite MFL, Lopes RLC, Costa MMB. [Mechanical-thermal stimulation of the palatoglossus pillars]. [Article in Portuguese]. Arq Gastroenterol. 2007;44 221-6.

5. Costa MM, Almeida JT, Sant'Anna E, Pinheiro GM. Viscosities reproductive patterns for use in videofluoroscopy and rehabilitation therapy of dysphagic patients. Arq Gastroenterol. 2007:44:297-303.

6. Simão Mde A, Alacid CA, Rodrigues KA, Albuquerque C, Furkim AM. Incidence of tracheal aspiration in tracheotomized patients in use of mechanical ventilation. Arq Gastroenterol. 2009;46:311-4.

7. Costa MM, Lemme EM. Coordination of respiration and swallowing: functiona pattern and relevance of vocal folds closure. Arq Gastroenterol. 2010;47:42-8.

8. Costa MMB. Videofluoroscopy: the gold standard exam for studying swallowing and its dysfunction. Arq Gastroenterol. 2010;47:327-8.

9. Cola PC, Gatto AR, Silva RG, Spadotto AA, Schelp AO, Henry MA. The influence of sour taste and cold temperature in pharyngeal transit duration in patients with stroke. Arq Gastroenterol. 2010;47:18-21.

10. Dantas RO, Alves LM, Santos CM, Cassiani R de A. Possible interaction of gender and age on human swallowing behavior. Arq Gastroenterol. 2011;48:195-8.

11. Baroni AF, Fábio SR, Dantas RO. Risk factors for swallowing dysfunction in stroke patients. Arq Gastroenterol. 2012;49:118-24.
12. Dalmazo J, Aprile LR, Dantas RO. Esophageal contractions, bolus transit and perception of transit after swallows of liquid and solid boluses in normal subjects. Arq Gastroenterol. 2012;49:250-4

13. Nicaretta DH, Rosso AL, Mattos JP, Maliska C, Costa MM. Dysphagia and sialorrhea: the relationship to Parkinson's disease. Arq Gastroenterol. 2013;50:42-9.

14. Bonadiman A, Teixeira AC, Goldenberg A, Farah JF. Dysphagia after laparoscopic total fundoplication: anterior or posterior gastric wall fundoplication? Arq Gastroenterol. 2014;51:113-7.

15. Alves LM, Secaf M, Dantas RO. Effect of a bitter bolus on oral, pharyngeal and esophageal transit of healthy subjects. Arq Gastroenterol. 2013;50:31-4.

16. Scheeren B, Maciel AC, Barros SG. Videofluoroscopic swallowing study: esophageal alterations in patients with dysphagia. Arq Gastroenterol. 2014 51:221-5.

17. Nascimento WV, Santos CM, Cassiani RA, Dantas RO. Influence of age on swallows of a highly viscous liquid bolus. Arq Gastroenterol. 2015;52:32-6.

18. Silva AC, Aprile LR, Dantas RO. Effect of gum chewing on air swallowing, saliva swallowing and belching. Arq Gastroenterol. 2015;52:190-4

19. Dantas RO, Santos CM, Cassiani RA, Alves LM, Nascimento WV. Postfundoplication dysphagia causes similar water ingestion dynamics as achalasia. Arq Gastroenterol. 2016;53:98-102

20. Santos CM, Cassiani RA, Dantas RO. Videofluoroscopic evaluation of swallows in anorexia nervosa. Arq Gastroenterol. 2016;53:136-40.

21. Pontes ÉS, Amaral AK, Rêgo FL, Azevedo EH, Silva PO. Quality of life in swallowing of the elderly patients affected by stroke. Arq Gastroenterol. 2017:54:27-32.

22. Moda I, Ricz HMA, Aguiar-Ricz LN, Dantas RO. Swallowing in patients with laryngitis. Arq Gastroenterol. 2018;55:50-4

23. Costa MMB. Neural control of swallowing. Arq Gastroenterol. 2018;55 (Suppl 1):61-75.

24. Costa TV, Dantas RO. Altered esophageal motility during perception of bolus transit in healthy volunteers. Arq Gastroenterol. 2019;56:386-9. 